\title{
Effectiveness of Cryptosporidium spp. oocysts detection and enumeration methods in water and milk samples
}

[Eficácia de métodos de detecção e enumeração de oocistos de Cryptosporidium spp. em amostras de água e leite]

\author{
E.C.L. Machado ${ }^{1}$, T.L.M. Stamford ${ }^{1}$, L.C. Alves $^{2}$, R.G. Melo ${ }^{1}$, N.K.S. Shinohara ${ }^{3}$ \\ ${ }^{1}$ Departamento de Nutrição - Centro de Ciências da Saúde - UFPE \\ Av. Professor Moraes Rego, 1235 \\ 50670-901 - Recife, PE \\ ${ }^{2}$ Departamento de Medicina Veterinária - UFRPE - Recife, PE \\ ${ }^{3}$ Departamento de Tecnologia Rural - UFRPE - Recife, PE
}

\begin{abstract}
Cryptosporidium spp. oocyst recovery in water and milk samples was evaluated. Samples were inoculated with a suspension of $1.2 \times 10^{7}$ Cryptosporidium spp. oocysts and submitted to centrifugal flotation, using different solutions (sucrose, $\mathrm{NaCl}, \mathrm{MgSO}_{4}, \mathrm{ZnSO}_{4}, \mathrm{AlSO}_{4}, \mathrm{NH}_{4} \mathrm{SO}_{4} 40 \%$ and $\mathrm{NH}_{4} \mathrm{SO}_{4} 80 \%$ ). Centrifugation of the samples was carried out in two stages for concentration using two methods that differed in the order in which the saturated solutions were used, namely only in the first stage of method I and only in the second stage of method II. Oocyst identification was performed using the Kinyoun and Koster histochemical staining techniques. Samples analyzed by method I showed different degree of oocyst recovery, namely $10.9 \%$ with $\mathrm{NaCl}$ and $42.5 \%$ with $\mathrm{MgSO}_{4}$ in water and milk samples, while those samples analyzed by method II showed $10.6 \%$ with $\mathrm{NaCl}$ and $5.3 \%$ with sucrose in water and milk, respectively. Histochemical staining methods have no influence on the degree of oocysts recovery. The efficiency of Cryptosporidium spp. oocysts recovery methods depends on the nature and composition of the sample and on the methodology used for oocyst concentration.
\end{abstract}

Keywords: oocyst, Cryptosporidium spp., concentration methods, water, milk

\section{RESUMO}

Avaliou-se a recuperação de oocistos de Cryptosporidium spp. em amostras de água e leite. As amostras foram contaminadas experimentalmente com uma suspensão de $1,2 \times 10^{7}$ oocistos de Cryptosporidium spp. e concentradas por centrifugo-flutuação para comparação entre diferentes substâncias (sacarose, $\mathrm{NaCl}, \mathrm{MgSO}_{4}, \mathrm{ZnSO}_{4}, \mathrm{AlSO}_{4}, \mathrm{NH}_{4} \mathrm{SO}_{4} 40 \%$ e $\mathrm{NH}_{4} \mathrm{SO}_{4} 80 \%$ ). A centrifugação das amostras foi realizada em duas etapas para concentração utilizando-se dois métodos, diferentes pela ordem do uso das soluções saturadas no procedimento, na primeira etapa de concentração do método I, e na segunda etapa, do método II. A identificação do oocisto foi realizada mediante as técnicas de coloração histoquímica Kinyoun e Koster modificado. O grau de recuperação de oocistos foi 10,9\% com $\mathrm{NaCl}$ e 42,5\% com $\mathrm{MgSO}_{4}$ nas amostras de água e leite, respectivamente (método I), e de 10,6\% com $\mathrm{NaCl}$ e 5,3\% com sacarose nas amostras de água e leite, respectivamente (método II). Os métodos de coloração histoquímica não influenciaram nos resultados. A eficácia dos métodos de recuperação de oocistos de Cryptosporidium spp. depende da natureza e composição da amostra e da metodologia usada para a concentração dos oocistos na amostra.

Palavras-chave: oocisto, Cryptosporidium spp., métodos de concentração, água, leite

Recebido em 26 de julho de 2004

Aceito em 13 de outubro de 2005

*Autor para correspondência (corresponding author)

E-mail: erilane@ig.com.br 


\section{INTRODUCTION}

Criptosporidiosis is an important disease related to public health. The zoonotic potential of Cryptosporidium parvum is not very clear. Moreover, it occurs in several species of animals and it increases the risk of infection by animal contact or by ingestion of contaminated food and water. Once a carrier, the individual shows gastroenteric clinical symptoms that can be severe and even lead to death. It may happen if they are immunodeficient individuals, such as HIV positive patients. Self-limiting patients may act as asymtomatic carriers of great epidemiological interest (Lima et al., 2001). The role of $C$. parvum as a waterborne pathogen has been described and animals are believed to be the main transmitters. However, epidemiological features of this parasitic protozoa lead to the assumption that the incidence of Cryptosporidium spp. in aquatic environment is underestimated. The lack of accurate proper methods for the detection of oocysts in water contributed to this report (Lima and Stamford, 2003).

Despite the reports relating cryptosporidiosis involving the consumption of different foods without adequate thermal treatment, the presence of Cryptosporidium spp. oocysts has been confirmed only in vegetables (Ortega et al., 1997), bivalve mollusks (Freire-Santos et al., 2000) and water (Luna et al., 2002).

Several methods have been proposed for Cryptosporidium detection but none has yet achieved general acceptance (Smith, 1998). In spite of the existence of sophisticated methods for identifying Cryptosporidium oocysts, such as molecular biology, they are all preceded by oocyst concentration methods in the sample in order to obtain a satisfactory result. It is possible to analyze milk and other liquid food similar to water (Smith, 1993). This analysis is divided into filtration, elution, concentration, purification and identification (Smith, 1998).

Cryptosporidium spp. oocyst recovery may be influenced by different factors such as the nature and type of sample, oocyst concentration and the methodology used for oocyst concentration and identification (Vesey et al., 1993; LeChevallier et al., 1995; Deng and Cliver, 1999). Emphasis should be laid on the importance of the association of a procedure for oocyst concentration with the identification methods when its specificity depends on oocyst integrity (Vesey et al., 1993).

This study aimed to appraise methods of Cryptosporidium spp. oocyst recovery in water and milk samples through the concentration of the centrifugal flotation technique.

\section{MATERIALS AND METHODS}

In the experimental assay, samples of public water supply and pasteurized milk type " $C$ " were used. Samples $(100 \mathrm{ml})$ were inoculated with nonpurified Cryptosporidium spp. oocysts (LeChevallier et al., 1995) that were extracted from fecal suspension and kept in $10 \%$ formaldehyde. The average number of oocysts was determined before inoculation of the samples and after three replicates according to Kaucner and Stinear (1998), and a suspension $(0.5 \mu \mathrm{l})$ was directly analyzed (LeChevallier et al., 1995) by the Kinyoun methodology (Brasil, 1996). Oocyst counting was made by light microscopy using magnification 40× (Oliveira and Germano, 1992).

After inoculating $1.2 \times 10^{7}$ Cryptosporidium spp. oocysts, the samples were homogenized and distributed into glass tubes for centrifugation, which was performed at $206 \times \mathrm{g}$, for 10 minutes (Deng and Cliver, 1999) using two stages for both sample concentration and reconcentration by means of two different methods: method I suggested by Webster et al. (1996) and method II proposed by Kageruka et al. (1984) (Fig. 1).

In water samples, the first centrifugation (method I) was performed by adding $5 \mathrm{ml}$ of the sample into centrifuge tubes with $5 \mathrm{ml}$ of each solution A (sucrose, density $1.06 \mathrm{~g} \mathrm{ml}^{-1} ; 320 \mathrm{gl}^{-1}$ ), B (sodium chloride, density $\left.1.15 \mathrm{gml}^{-1} ; \quad 400 \mathrm{gl}^{-1}\right)$, $\mathrm{C}$ (magnesium sulphate, density $1.30 \mathrm{gml}^{-1}$; $750 \mathrm{gl}^{-1}$ ), D (zinc sulphate, density $1,20 \mathrm{gml}^{-1}$; $400 \mathrm{gl}^{-1}$ ) and $\mathrm{E}$ (aluminium sulphate, density $\left.1.11 \mathrm{gml}^{-1} ; 300 \mathrm{gl}^{-1}\right)$, plus solutions $\mathrm{F}$ and $\mathrm{G}$ (ammonium sulphate, $40 \% \quad(\mathrm{w} / \mathrm{v})$, density $1.11 \mathrm{gml}^{-1}$ and $80 \%(\mathrm{w} / \mathrm{v})$, density $1.20 \mathrm{gml}^{-1}$, respectively). After the first centrifugation, two further ones were carried out making use of the resulting supernatant (SN) and sediment (SD), both adjusted to the volume of $2 \mathrm{ml}$, and resuspending them in $8 \mathrm{ml}$ of distilled water. 


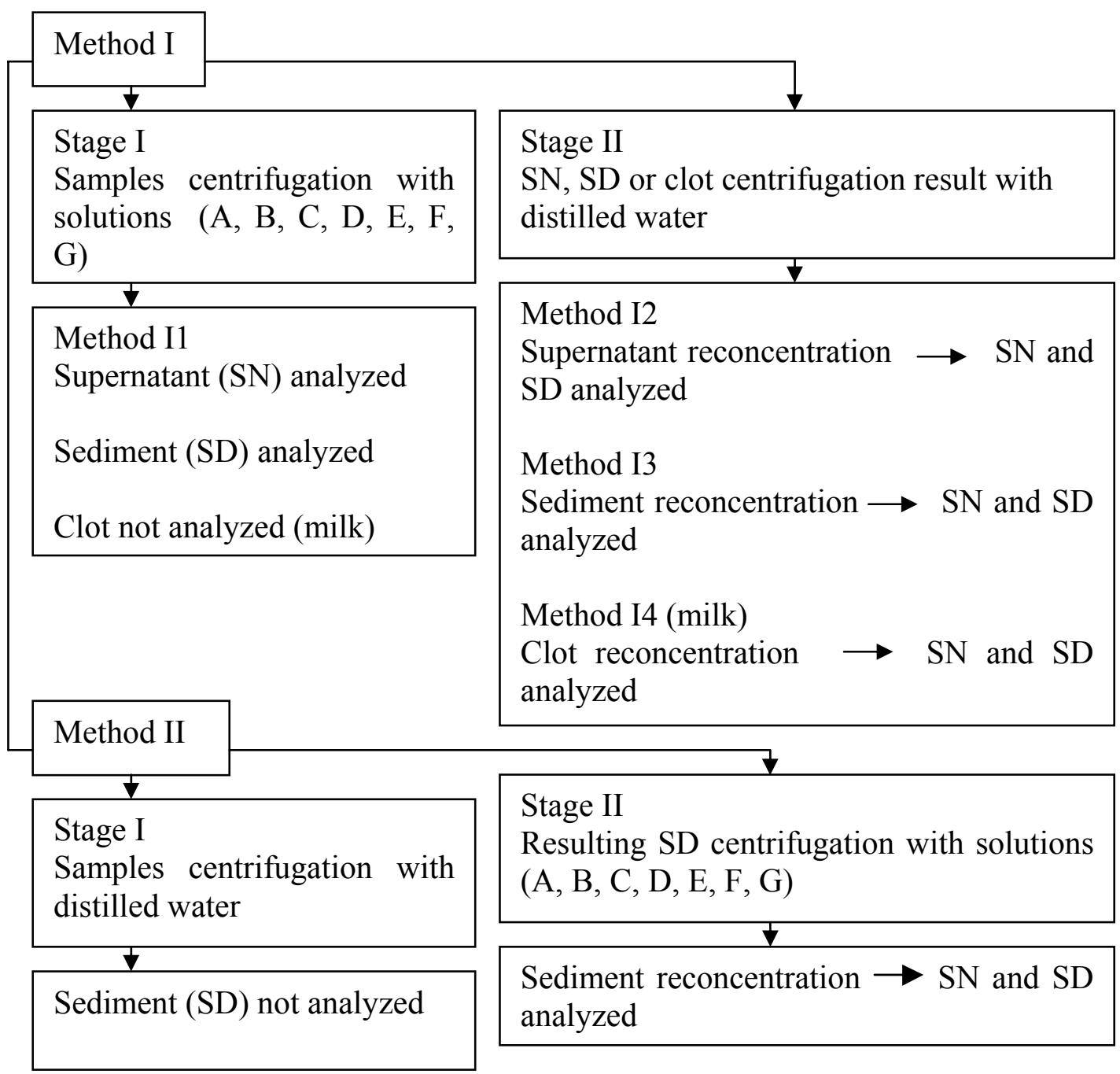

Figure 1. Diagram showing different methods for concentration and reconcentration of Cryptosporidium oocyst in water and milk samples

The same procedure was applied to the milk sample, but due to the coagulation of its mixture with the sulphate solutions (C, D, E, F and G) in the first centrifugation and the remaining clot fixed in the intermediate layer of the tube, it was necessary to transfer the sediment $(2 \mathrm{ml})$ to another tube and a new centrifugation step was done before analysis. Although the mixing of milk with solutions A and B produced no clot, the procedure was carried out in the same way. The resulting clot was washed out with $10 \mathrm{ml}$ distilled water and transferred to a recipient where it was dissolved, sieved and centrifuged.
In method II, the same procedure for water and milk samples was used. In the first stage, $5 \mathrm{ml}$ of the sample was centrifuged with distilled water, while in the second stage, the resulting sediment (2ml) was mixed with $8 \mathrm{ml}$ of solutions A to G. After each centrifugation, except for the first stage of method II, water and milk smears were made with $5 \mu \mathrm{l}$ of SN and SD.

In method I, codification refers to the type of phase resulting from the first centrifugation (I1), which was used for sample reconcentration. In the water samples, reconcentration was obtained 
from the supernatant and sedimentary phases, which were termed I 2 and I3, respectively. As to the milk sample reconcentration, it was also obtained from the coagulated intermediate phase, named I4, which happened only when solutions C, D, E, F and G were used.

Kinyoun's technique (Brasil, 1996) and Koster's modified one (Kageruka et al., 1984) were used to stain the smears. Oocyst detection and enumeration were carried out according to Oliveira and Germano (1992). In addition, the total number of oocysts and the percentage recovered were calculated by the equations described by Oliveira and Germano (1992) and Deng and Cliver (1999): [(oocysts counted in the field $\times$ volume of the sample/volume analyzed)/oocysts inoculated] $\times 100$ of sample.

Analysis of variance was performed and Tukey test $(\mathrm{P} \leq 0.05)$ was used to compare the means.

\section{RESULTS AND DISCUSSION}

Cryptosporidium spp. oocyst recovery showed a significant response $(\mathrm{P}<0.05)$ in water and milk samples, regardless of the concentration methods and solutions used (Table 1). These results are in accordance with Nieminski et al. (1995), Deng and Cliver (1999) and Kuczynska and Shelton (1999), who proposed the recovery of Cryptosporidium spp. oocysts by analyses of sediment, which can be done before or after the stage of oocyst concentration by the centrifugal flotation process.

Table 1. Mean number of Cryptosporidium spp. oocysts recovered from the supernatant and sediment phases in water and milk samples

\begin{tabular}{lccc}
\hline \multirow{2}{*}{ Assay } & \multirow{2}{*}{ Sample } & \multicolumn{2}{c}{$\begin{array}{c}\text { Number oocysts } \times 2,0 \times 10^{3} \\
\text { Phase }\end{array}$} \\
\cline { 3 - 4 } & & Supernatant & Sediment \\
\hline 1 & Water & $0 \mathrm{~b}$ & $226.3 \mathrm{a}$ \\
2 & Milk & $0.8 \mathrm{~b}$ & $155.8 \mathrm{a}$ \\
\hline
\end{tabular}

Means followed by equal letters on the same row do not differ by Tukey test $(\mathrm{P}>0.05)$.

Oocyst sedimentation probably occurred because the oocysts were not found in free form, but possibly adhered to fecal solids as described by Kuczynska and Shelton (1999). Maybe, it happened due to the influence of the reagents for the viability of the oocysts (Bukhari and Smith, 1995) and the absence of detergent solutions in the processing of samples (Smith, 1993), but LeChevallier et al. (1995) did not report the influence of these solutions in the recovery of oocysts. According to Bukhari and Smith (1995), the surface of the nonviable oocysts was more likely to adhere to the fecal solids. Moreover, the sucrose and zinc sulphfate solutions concentrate viable oocysts selectively. LeChevallier et al. (1995) stated that the Percoll-sucrose gradient (specific gravity $1.15 \mathrm{~g} \mathrm{ml}^{-1}$ ) usually concentrates empty oocysts revealing a $100 \%$ recovery.

In relation to the water samples, Table 2 shows that in methods I1, I3 and II the highest degree of recovery was obtained using solution $\mathrm{B}$, which was $(\mathrm{P}>0.05)$ similar to the other solutions, except solution E. Recovery percentages ranged from $0.3 \%$ (solution $\mathrm{E}$, method II) to $10.9 \%$ (solution B, method I3), and the absence of oocysts was detected only after using method $\mathrm{I} 2$. The ammonium sulphate solution produced a higher oocyst concentration, since it achieved recovery percentages of $8.3 \%$ and $9.4 \%$ in methods I1 and I3, respectively. These values are similar to those obtained with sodium chloride, namely $8.4 \%$ and $10.9 \%$. However, due to the absence of oocysts in the supernatants, Table 2 shows only the results of oocyst recovery obtained in the sediments.

The conventional concentration method carried out in three stages (two stages by centrifugal sedimentation mediated by one of centrifugal flotation) was evaluated by Kuczynska and Shelton (1999) for Cryptosporidium spp. oocyst detection in fecal samples and it was observed that the $\mathrm{NaCl}$ solution concentrated a higher number of Cryptosporidium spp. oocysts $(18.7 \%)$, possibly because monovalent cations of $\mathrm{NaCl}$ disperse particles and allow separation of oocysts from waste. These authors obtained a positive result by using centrifugal flotation. In the present study, however, no positive results were obtained using their technique (method I2), owing to the absence of oocysts. The presence of many residues contained in the inoculum was sufficient to result in the duality between flotation and sedimentation of the oocysts in the sample. 
Table 2. Means of the total number of Cryptosporidium spp. oocysts and the percentage recovered in the sediments of the water samples

\begin{tabular}{|c|c|c|c|c|}
\hline \multirow[t]{2}{*}{ Solution } & \multicolumn{4}{|c|}{$\begin{array}{c}\text { Number of oocysts x } 2.0 \times 10^{3} \\
(\% \text { oocysts }=\text { mean })^{*} \\
\text { Method }\end{array}$} \\
\hline & I1 & I2 & $\mathrm{I} 3$ & II \\
\hline A & $\begin{array}{c}130.8 \mathrm{a} \\
(2.2)\end{array}$ & 0 & $\begin{array}{l}434 \mathrm{a} \\
(7.3)\end{array}$ & $\begin{array}{c}144 \mathrm{a} \\
(2.4)\end{array}$ \\
\hline B & $\begin{array}{c}504.5 \mathrm{a} \\
(8.4)\end{array}$ & 0 & $\begin{array}{c}652 \mathrm{a} \\
(10.9)\end{array}$ & $\begin{array}{c}632,2 \mathrm{a} \\
(10.6)\end{array}$ \\
\hline $\mathrm{C}$ & $\begin{array}{c}191.5 \mathrm{a} \\
(3.2)\end{array}$ & 0 & $\begin{array}{c}357.3 \mathrm{a} \\
(6.0)\end{array}$ & $\begin{array}{c}110.2 \mathrm{a} \\
(1,8)\end{array}$ \\
\hline D & $\begin{array}{c}338 \mathrm{a} \\
(5.6)\end{array}$ & 0 & $\begin{array}{c}420.6 \mathrm{a} \\
(7.0)\end{array}$ & $\begin{array}{c}338 \mathrm{a} \\
(5.6)\end{array}$ \\
\hline $\mathrm{E}$ & $\begin{array}{c}14.8 \mathrm{~b} \\
(0.3)\end{array}$ & 0 & $\begin{array}{c}50.7 \mathrm{~b} \\
(0.9)\end{array}$ & $\begin{array}{c}44.3 \mathrm{~b} \\
(0.7)\end{array}$ \\
\hline $\mathrm{F}$ & $\begin{array}{r}495 \mathrm{a} \\
(8.3)\end{array}$ & 0 & $\begin{array}{c}564 \mathrm{a} \\
(9.4)\end{array}$ & $\begin{array}{c}260.7 \mathrm{a} \\
(4.4)\end{array}$ \\
\hline G & $\begin{array}{c}108.4 \mathrm{a} \\
(1.8)\end{array}$ & 0 & $\begin{array}{c}357.5 \mathrm{a} \\
(6.0)\end{array}$ & $\begin{array}{c}187.4 \mathrm{a} \\
(3.1)\end{array}$ \\
\hline
\end{tabular}

Means followed by equal letters on the same column do not differ by Tukey test $(\mathrm{P}>0.05)$

*Means determined after six replicates

I1 (concentration) $=1^{\text {st }}$ stage, I2 (reconcentration of supernatant), I3 (reconcentration of sediment), $=2^{\text {nd }}$ stage/method I, II (reconcentration of sediment) $=2^{\text {nd }}$ stage/method II.

A (sucrose), B $(\mathrm{NaCl}), \mathrm{C}\left(\mathrm{MgSO}_{4}\right), \mathrm{D}\left(\mathrm{ZnSO}_{4}\right), \mathrm{E}\left(\mathrm{AlSO}_{4}\right)$, $\mathrm{F}\left(\mathrm{NH}_{4} \mathrm{SO}_{4} 40 \%\right), \mathrm{G}\left(\mathrm{NH}_{4} \mathrm{SO}_{4} 80 \%\right)$.

Table 3 shows that the method used had some influence for the milk samples on the effectiveness of the solutions applied and, therefore, produced different results between the solutions in the concentration of oocysts in the samples. In method I1, the highest oocyst recovery $(11.6 \%)$ was obtained using solution $\mathrm{F}$, although no significant $(\mathrm{P}>0.05)$ difference was observed between the means of all the solutions. This can be explained by the variability among the samples submitted to the same treatment.

In method I2, despite the lack of a good recovery, the highest value $(0.7 \%)$ was obtained using solution $\mathrm{C}$. This result represents flotation among oocysts in the first stage of the procedure, so the flotation could be seen when the supernatant volume was reprocessed and the sediment analyzed. Cryptosporidium spp. oocyst recovery was obtained by Luna et al. (2002) when using the same concentration method (centrifugal flotation followed by centrifugal sedimentation), but applying sucrose solution in the analysis of water samples.
Table 3. Means of the total number of Cryptosporidium spp. oocysts and the percentage recovered from the sediments of the milk samples

\begin{tabular}{|c|c|c|c|c|c|}
\hline \multirow[t]{2}{*}{ Solution } & \multicolumn{5}{|c|}{$\begin{array}{c}\text { Number of oocysts } \times 2.0 \times 10^{3} \\
(\% \text { of oocysts }=\text { mean })^{*} \\
\text { Method }\end{array}$} \\
\hline & I1 & I2 & I3 & I4 & II \\
\hline A & $\begin{array}{l}51.5 \mathrm{a} \\
(0.9)\end{array}$ & $0 \mathrm{a}$ & $\begin{array}{c}134.8 \mathrm{ab} \\
(2.2)\end{array}$ & - & $\begin{array}{c}317.5 \mathrm{a} \\
(5.3)\end{array}$ \\
\hline B & $\begin{array}{l}6.3 \mathrm{a} \\
(0.1)\end{array}$ & $\begin{array}{c}1.7 \mathrm{a} \\
(0.036)\end{array}$ & $\begin{array}{c}225.5 \mathrm{ab} \\
(3.2)\end{array}$ & - & $\begin{array}{c}69.7 \mathrm{a} \\
(1.1)\end{array}$ \\
\hline $\mathrm{C}$ & $\begin{array}{l}17 \mathrm{a} \\
(0.3)\end{array}$ & $\begin{array}{c}39.3 \mathrm{a} \\
(0.7)\end{array}$ & $\begin{array}{c}287.7 \mathrm{ab} \\
(3.8)\end{array}$ & $\begin{array}{c}2551.3 \mathrm{a} \\
(42.5)\end{array}$ & $\begin{array}{c}32.2 \mathrm{a} \\
(0.6)\end{array}$ \\
\hline $\mathrm{D}$ & $\begin{array}{c}0.5 \mathrm{a} \\
(0.01)\end{array}$ & $0 \mathrm{a}$ & $0 \mathrm{~b}$ & $\begin{array}{l}8.5 \mathrm{~b} \\
(0.2)\end{array}$ & $\begin{array}{c}19.3 \mathrm{a} \\
(0.4)\end{array}$ \\
\hline $\mathrm{E}$ & $0 \mathrm{a}$ & $0 \mathrm{a}$ & $0 \mathrm{~b}$ & $\begin{array}{c}11.8 \mathrm{~b} \\
(0.2)\end{array}$ & $\begin{array}{c}24.5 \mathrm{a} \\
(0.4)\end{array}$ \\
\hline $\mathrm{F}$ & $\begin{array}{c}691.5 \mathrm{a} \\
(11.6)\end{array}$ & $\begin{array}{c}0.2 \mathrm{a} \\
(0.003)\end{array}$ & $\begin{array}{c}541.3 \mathrm{a} \\
(9.1)\end{array}$ & $\begin{array}{c}368.8 \mathrm{~b} \\
(6.2)\end{array}$ & $\begin{array}{l}9.7 \mathrm{a} \\
(0.2)\end{array}$ \\
\hline $\mathrm{G}$ & $0 \mathrm{a}$ & $0 \mathrm{a}$ & $0 \mathrm{~b}$ & $\begin{array}{c}35.5 \mathrm{~b} \\
(0.7)\end{array}$ & $\begin{array}{l}7.7 \mathrm{a} \\
(0.2)\end{array}$ \\
\hline
\end{tabular}

Means followed by equal letters in the same column do not differ by Tukey test $(\mathrm{P}>0.05)$.

* Means determined after six replicates.

I1 (concentration) $=1$ st stage, I2 (reconcentration of supernatant), I3 (reconcentration of sediment), I4 (reconcentration of clot) $=2^{\text {nd }}$ stage/method I, II $($ reconcentration of sediment $)=2^{\text {nd }}$ stage $/$ method II.

A (sucrose), $\mathrm{B}(\mathrm{NaCl}), \mathrm{C}\left(\mathrm{MgSO}_{4}\right), \mathrm{D}\left(\mathrm{ZnSO}_{4}\right), \mathrm{E}\left(\mathrm{AlSO}_{4}\right)$, $\mathrm{F}\left(\mathrm{NH}_{4} \mathrm{SO}_{4} 40 \%\right), \mathrm{G}\left(\mathrm{NH}_{4} \mathrm{SO}_{4} 80 \%\right)$.

In method I2, the absence and presence of oocysts were verified in the sediments from water (Table 2) and milk (Table 3) samples, respectively. The different behavior of the samples may have been influenced by the sample composition if one takes into account the fact that water is a homogeneous solution, while milk is a complex physicochemical emulsion, composed by lipids, proteins, mineral salts and vitamins.

In method I3, the largest degree of recovery $(9.1 \%)$ was obtained with solution $\mathrm{F}$, although it did not differ $(\mathrm{P}>0.05)$ from the solutions $\mathrm{C}, \mathrm{B}$ and $\mathrm{A}$ with a recovery percentage between 2.2 and $3.8 \%$. It was not possible to recover oocysts with the other solutions.

In the milk clot analysis (method I4), the $42.5 \%$ oocysts recovery were obtained by using solution $\mathrm{C}$, which were $(\mathrm{P}<0.05)$ higher than the results of all the other solutions, thus emphasizing the lack of clot formation when using sucrose and sodium chloride. A similar occurrence in the study of Vesey et al. (1993), when a recovery of $73.7 \%$ 
was obtained after analysis of the samples from public water supply, in which the flocculation with $\mathrm{CaCO}_{3}$ method was used, was observed. However, in that study sulphamic acid was used for the dissolution of the floccules, whereas in the present study it was used a different procedure, in which the clot was manipulated with a glass stick.

In method II, the best results were obtained with solution A, but they were not significantly different from the ones obtained with the other solutions $(\mathrm{P}>0.05)$.

In water samples, method I3 (Table 4), which represents the second stage of concentration $\left(2^{\text {nd }}\right.$ centrifugation), showed a value $(\mathrm{P}<0.05)$ higher than the others. These results are in accordance with those of Kuczynska and Shelton (1999), which show that sample processing in more than one stage results in a larger concentration of oocysts. This occurs especially when sample concentration is achieved at a stage subsequent to centrifugal flotation. Nevertheless, these observations differ from the results of Nieminski et al. (1995) in that after centrifugal flotation stage there was a decrease in the recovery percentage from $78 \%$ to $69 \%$ when using Percoll-sucrose. When the investigation was performed on the sediment from the centrifugal flotation stage, method II, the result remained lower to that of method I3.

The behavior was similar with milk samples. Therefore, methods I3 (sediment reconcentration) and I4 (clot reconcentration) were chosen to detect Cryptosporidium spp. in water and milk samples, respectively. Method I is preferable to method II, probably because of the order in which the concentration solutions were added to the samples in the first (method I) or in the second (method II) stage.

Fig. 2 shows the results of the recovery of oocysts according to the method of concentration and the solution used. The results showed that level of recovery in milk samples with the regeneration of the clot (method I4), as a result of the application of solution $\mathrm{C}$, was higher than the largest number of oocysts found in water using solution $\mathrm{B}(\mathrm{NaCl})$, in method I3. Probably the occurrence of coagulation contributed to the increase in concentrated Cryptosporidium spp. oocysts when a mass shrinkage produced a semisolid structure in the used sample.

The experimental recovery of Cryptosporidium spp. oocysts may be influenced by the nature and type of the sample, type of solutions (Kuczynska and Shelton, 1999) and methodology applied in oocyst concentration (Vesey et al., 1993; LeChevallier et al., 1995). In water samples, turbid conditions must be taken into consideration, particularly the degree of inorganic (chemical) or organic (biological) impurity they may contain (Nieminski et al., 1995; Medema et al., 1998). As for food samples, their varying composition may have some influence upon oocyst recovery (Deng and Cliver, 1999). Concerning Kinyoun and Koster's staining methods, no differences $(\mathrm{P}>0.05)$ were found (Lima et al., 2004). Both methods may, therefore, be used in identifying Cryptosporidium spp. oocysts in both water and milk samples.

Table 4. Mean number of Cryptosporidium spp. oocysts recovered per sample through the different concentration methods in assays 1 (water) and 2 (milk)

\begin{tabular}{|c|c|c|c|c|c|c|}
\hline \multirow[t]{2}{*}{ Assay } & \multirow[t]{2}{*}{ Sample } & \multicolumn{5}{|c|}{$\begin{array}{l}\text { Number of oocysts x } 2,0 \times 10^{3} \\
\text { Method }\end{array}$} \\
\hline & & I1 & $\mathrm{I} 2$ & I3 & I4 & II \\
\hline 1 & Water & $254.7 b$ & $0 \mathrm{c}$ & $405.2 \mathrm{a}$ & & $245.2 b$ \\
\hline 2 & Milk & $54.8 \mathrm{bc}$ & $3.0 \mathrm{c}$ & $85.1 \mathrm{ab}$ & $298.5 a$ & $35.4 b c$ \\
\hline
\end{tabular}

Means followed by the same letters on the same row do not differ by Tukey test $(\mathrm{P}>0.05)$.

MSD in water with data transformed by root $(X+1)=5.43409$.

MSD in milk with data transformed by root $(X+1)=2.60730$.

I1 $(1$ st concentration $)=1$ st stage, I 2 (reconcentration of supernatant), I3 (reconcentration of sediment), I4 (reconcentration of clot) $=$ 2nd stage/method I, II (reconcentration of sediment) $=2$ nd stage/method II. 


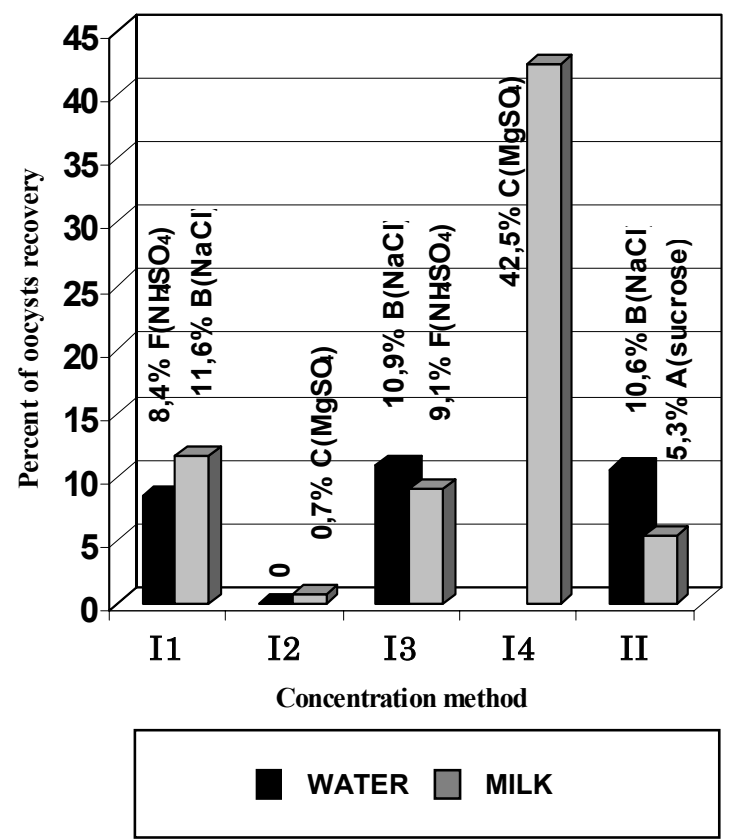

Figure 2. Results obtained in each method of concentration (I1, I2, I3, I4 and II) and respective solutions used for recovery of Cryptosporidium spp. oocysts in water and milk samples.

In conclusion, the nature of the samples influence on the performance of solutions and the effectiveness of concentration methods for oocyst recovery. Moreover, if coagulation occurs during the concentration procedure, this will favor the increase of Cryptosporidium spp. oocyst concentration. Finally, in the concentration method, which uses high density solutions from the beginning of the procedure, the process of reconcentration is more successful, especially when sodium chloride and magnesium sulphate are added to water and milk samples, respectively.

\section{REFERENCES}

BRASIL. MINISTÉRIO DA SAÚDE. Infecções oportunistas por parasitas em AIDS-Técnicas de diagnóstico. Brasília/DF. 1996. 27p.

BUKHARI, Z.; SMITH, H.V. Effect of three concentration techniques on viability of Cryptosporidium parvum oocysts recovered from bovine feces. J. Clin. Microbiol., v.46, p.113$121,1995$.
DENG, M.Q.; CLIVER, D.O. Cryptosporidium parvum studies with dairy products. Int. J. Food Microbiol., v.46, p.113-121, 1999.

FREIRE-SANTOS, F.; LOPEZ, A.M.O.; CASTIBLANCO, C.A.V. et al. Detection of Cryptosporidium oocysts in bivalve mollusks destined for human consumption. J. Parasitol., v.86, p.853-854, 2000.

KAGERUKA, P.; BRANDT, J.R.A.; TAELMAM, H. et al. Modified Koster staining method for the diagnosis of cryptosporidiosis. Am. Soc. Belge Trop. Med., v.64, p.171-175, 1984.

KAUCNER, C.; STINEAR, T. Sensitive and rapid detection of Giardia cysts and Cryptosporidium parvum oocysts in largevolume water samples with wound fiberglass cartridge filters and reverse transcription-PCR. Appl. Environ. Microbiol., v.64, p.1743-1749. 1998.

KUCZYNSKA, E.; SHELTON, D.R. Method for detection and enumeration of Cryptosporidium parvum oocysts in feces, manures, and soils. Appl. Environ. Microbiol., v.65, p.2820-2826, 1999. 
LeCHEVALLIER, M.W.; NORTON, W.D.; SIEGEL, J.E. et al. Evaluation of the immunofluorescence procedure for detection of Giardia cysts and Cryptosporidium oocysts in water. Appl. Environ. Microbiol., v.61, p.690697, 1995.

LIMA, E.C.; MELO, V.S.P.; BRITO, F.L.C. et al. Avaliação de diferentes técnicas de coloração histoquímica na identificação de oocistos de Cryptosporidium spp. em amostras de água e leite. Rev. Bras. Ciênc. Vet., v.11, p. 21-26, 2004.

LIMA, E.C.; STAMFORD, T.L.M. Cryptosporidium spp. no ambiente aquático: aspectos relevantes da disseminação e diagnóstico. Ciênc. Saúde Colet., v.8, p.791-800, 2003.

LIMA, E.C.; STAMFORD, T.L.M.; ALVES, L.C. et al. Importância da criptosporidiose para a saúde pública. Ciênc. Vet. Trop., v.4, p.229-239, 2001

LUNA, S.; LILIANA REES, L.; MISAEL, C. et al. Presencia de ooquistes de Cryptosporidium spp. en aguas superficiales en Costa Rica. Parasitol. Latinoam., v.57, p.63-65, 2002.

MEDEMA, G.J.; SCHETS, F.M.; TEUNIS, P.F.M. et al. Sedimentation of free and attached Cryptosporidium oocysts and Giardia cysts in water. Appl. Environ. Microbiol., v.64, p.44604466, 1998.

NIEMINSKI, E.C.; SCHAEFER, F.W.I.I.I.; ONGERTH, J.E. Comparison of two methods of
Giardia cysts and Cryptosporidium oocysts in water. Appl. Environ. Microbiol., v.61, p.17141719, 1995.

OLIVEIRA, C.A.F.; GERMANO, P.M.L. Estudo da ocorrência de enteroparasitas em hortaliças comercializadas na região metropolitana de São Paulo-SP, Brasil-II/ Pesquisa de protozoários intestinais. Rev. Saúde Públ., v.26, p.332-335, 1992.

ORTEGA, Y.R.; ROXAS, C.R.; GILMAN R.H. et al. Isolation of Cryptosporidium parvum and Cyclospora cayetanensis from vegetables collected in markets of an endemic region in Peru. Am. J. Trop. Med. Hyg., v.57, p.683-686, 1997.

SMITH, H.V. Detection of parasites in the environment. Parasitology, v.117, p.S113-141, 1998.

SMITH, J.L. Cryptosporidium and Giardia as agents of foodborne disease. J. Food Protect., v.56, p.451-461, 1993.

VESEY, G.; SLADE, J.S.; BYRNE, M. et al. A new method for the concentration of Cryptosporidium oocysts from water. J. Appl. Bacteriol., v.75, p.82-86, 1993.

WEBSTER, K.A.; SMITH, H.V.; GILES, M. et al. Detection of Cryptosporidium parvum oocysts in faeces: comparison of conventional coproscopical methods and polymerase chain reaction. Vet. Parasitol., v.61, p.5-13, 1996. 